\section{К вопросу экономии топлива на транспорте}

\author{
С. В. Беляев ${ }^{1}$ \\ Петрозаводский государственный университет
}

\section{АННОТАЦИЯ}

Статья посвящена проблемам экономии топлива на транспорте, анализируются возможные пути уменьшения расхода традиционных видов топлив и переход на использование альтернативных энергоносителей.

Ключевые слова: топливная экономичность, автомобиль, альтернативные топлива.

\section{SUMMARY}

Today's transportation system remains enormously dependent on oil, a lot of countries face major challenges in meeting the ever-increasing demand for transportation goods and services, while at the same time minimizing the adverse impact on energy resources, the environment and future prosperity. Vehicles powered by domestically produced alternative fuels, including ethanol, methanol, natural gas, electricity and biodiesel, already are on the market and available to consumers.

Keywords: fuel economy, vehicles, and alternative.

В настоящее время - время энергетических ограничений - приходится обращать пристальное внимание на всех основных потребителей топлива. Причем внимания заслуживают все каналы расхода энергии и особенно на автомобильном транспорте. В энергосберегающей политике вопросы потребления ресурсов, нормирования и стимулирования рационального их использования приобретают все большее значение. Одним из основных потребителей энергии является автомобильный транспорт, объемы производства которого с каждым годом возрастают. Вследствие этого работы по повышению экономичности автомобилей имеют большое значение. Возрастает роль автомобиля как основного вида личного транспорта. Свобода, предоставляемая личным автомобилем, будет, по-видимому, продолжать оставаться важным элементом жизни общества. При оценке перспектив развития автомобильной промышленности и совершенствования автомобилей следует иметь в виду чувствительность рынка к цене на топливо. По мере повышения топливной экономичности автомобилей экономия при каждом очередном ее повышении будет уменьшаться. В любой области, будь то совершенствование двигателя, трансмиссии или шин, по мере достижения предельных характеристик, соответствующих уровню современной технологии, скорость прогресса замедляется. По большинству пара-

\footnotetext{
${ }^{1}$ Автор - дочент кафедры промышленной теплотехники
}

(C) С. В. Беляев, 2003 метров, от которых зависит топливная экономичность, мы в настоящее время уже приближаемся к предельным значениям.

Транспортный комплекс развитых стран потребляет примерно половину мирового количества добываемой нефти. Между двумя нефтяными кризисами (1974 и 1978 гг.) во многих странах была разработана энергетическая политика, предусматривающая введение стандартов на топливную экономичность и внедрение энергосберегающих технологий.

Основные мероприятия, которые, по мнению многих специалистов, являются весьма актуальными и сегодня, включают:

- Создание современных автомобилей экономичных модификаций, использующих традиционные виды топлива (мероприятия заключаются в основном в совершенствовании конструкции двигателей и других агрегатов автомобиля);

- Повышение качества применяемых топливосмазочных материалов и вторичное использование масел и смазок;

- Совершенствование коммерческой (автопоезда, использование грузоподъемности, маршрутизация и т.п.) и технической (качество ТО и ремонта, учет, бортовые компьютеры, квалификация персонала) эксплуатации;

- $\quad$ Анализ условий применения топлив-заменителей на ближайшую перспективу (например, метанол и его смеси, природный и биологические газы), которые могут частично пополнить ресурсы нефтяных топлив, используемых традиционными автомобилями. Поиски в США в этом направлении от стадии научно-исследовательских и опытно-конструкторских работ сегодня перешли к активной фазе практической реализации. Так, например, американский Институт метанола информировал о создании развитой индустрии по производству метанола. Корпорация Daimler Chrysler представила автомобили, работающие на метаноле, и детальный план распространения их на рынке. Более того, на уровне президента недавно была проведена национальная неделя альтернативных топлив, целями которой являлись минимизация зависимости от импортируемых энергоносителей, охрана окружающей среды и стимулирование перспективных разработок;

- Поиски альтернативных видов топлив и конструкций автомобилей, исключающих в более отдаленной перспективе применение топлив нефтяного происхождения. К этим мероприятиям относится применение электроэнергии (аккумуляторные электромобили), гибридных автомобилей (в качестве источников энергии используются двигатели внутреннего сгорания и аккумуляторные батареи, а в качестве накопителей энергии - аккумуляторные батареи и маховиковые накопители; синтетические топлива и т. д.). Характерным для ведущих компаний в мире является опережающая научно-исследовательская 
и конструкторско-экспериментальная работа по созданию автомобилей будущего. Так, например, в США в рамках национальной программы PNGV (Partnership for New Generation of Vehicles) с целью разработки новых автомобилей, обладающих высокими топливной экономичностью, экологическими характеристиками, объединили усилия всемирно известные фирмы Chrisler, Ford и General Motors. Более того,к ним присоединились исследователи из нефтяных компаний Mobil, Amoco, Exxon при активном участии Департамента Энергетики.

Очередной технологический рывок, который предпринимают промышленно-развитые страны в этом направлении, еще меньше оставляет шансов для отечественных промышленности и компаний быть конкурентоспособными на мировом рынке. В случае реализации данных проектов промышленно-развитые страны действительно могут реально уменьшить свою зависимость от импорта нефти и, как крупнейшие ее импортеры, могут более активно влиять на понижение цены на нефть, что, безусловно, затронет экономические интересы России. В этой связи разработка подобной отечественной программы была бы крайне важной, правда, в отличие от американской, она должна быть нацелена на ослабление зависимости российской экономики от экспорта энергоносителей.
В современных условиях энергетический фактор все в большей степени оказывает влияние на экономическое и социальное развитие общества. Сегодня ни одна из проблем не волнует так остро, как проблема надежного и бесперебойного энергоснабжения.

Стратегия рационального использования топливоэнергетических ресурсов должна базироваться только на основе достоверного прогноза их запасов, дальнейшего развития эффективных энергоносителей, а также на совершенствовании традиционных транспортных систем.

\section{СПИСОК ЛИТЕРАТУРЫ}

1. Говорущенко Н. Я. Экономия топлива и снижение токсичности на автомобильном транспорте. М.: Транспорт, 1990. 135 с.

2. WHITE HOUSE PRESS RELEASE: 5/29. Clinton Names National Alternative Fuels Week.

3. Methanol Key to Daimler Chryslers Fuel Cell Vehicle Plans. Company Press Release. 3.03.99.

4. Oil - a national resource epilogue - looking to the future / Institute of Petroleum. London, 1998. 